\title{
Designing Jet Fan Ventilation for an Underground Car Park by CFD Simulations
}

\author{
Miroslava Kmecová1, Michal Krajčík ${ }^{1 *}$, Zuzana Straková1 \\ 1 Department of Building Services, Faculty of Civil Engineering, Slovak University of Technology in Bratislava, \\ Radlinského 11, 81005 Bratislava, Slovakia \\ * Corresponding author, e-mail: michal.krajcik@stuba.sk
}

Received: 14 May 2018, Accepted: 12 October 2018, Published online: 13 December 2018

\begin{abstract}
The aim of this study was to design a fire ventilation system with impulse jet fans for an underground car park. With respect to the number of parameters affecting the spread of smoke that need to be considered, there is a good chance of miscalculations if only conventional plain calculations are used in the design process. To avoid mistakes, visualize the fluid flow, and to compare the design variants it is practical to use computational fluid dynamics (CFD). In this study, CFD simulations were used to compare alternative designs of a fire ventilation system. In one alternative the exhaust shafts were located in both parts of the car park and the jet fans were directed to the corresponding shafts. The air exchange rate was 10-times per hour. In another alternative both exhaust shafts were located on one side opposite to the main air supply, and the air exchange rate was 15-times per hour. The results showed preference of the second alternative, when the smoke was completely exhausted and the visibility improved substantially, whereas in the first alternative the car park was not sufficiently ventilated even 600 seconds after the fire had been put out. The results emphasize that proper location of elements of the ventilation system is crucial to attain high efficiency of fire ventilation.
\end{abstract}

\section{Keywords}

fire ventilation, jet fans, CFD simulation, smoke, car park

\section{Introduction}

For modern buildings the installation of a mechanical ventilation system is essential to provide the required level of air quality and thermal comfort at favourable energy consumption throughout the whole year [1-3]. Besides the creation of an excellent indoor environment, an important task of mechanical ventilation is to ensure fire safety [4]. For big underground car parks typical, e.g., for large commercial buildings, fire ventilation with jet fans to move the polluted air to the main ventilation shafts has become popular and is being increasingly preferred over traditional ducted systems $[5,6]$. This system can be used both as day to day ventilation to remove airborne pollutants and as fire ventilation. The task of day to day ventilation is to remove the air polluted by combustion products originating from cars to prevent health damage to people. The fire ventilation exhausts the excessive heat and combustion products originating from the fire and simultaneously supplies fresh air to the car park to increase the safety of evacuated people and of the firemen.

Regardless of the design standard used, it is important to verify correctness of the proposed solution by CFD [7, 8].
The CFD simulations present a tool to analyse systems involving heat and mass transfer in a thorough and sophisticated manner by computer models, and to provide a view of the flow fields which would be otherwise difficult to visualize. The Fire Dynamics Simulator (FDS) has become a popular CFD tool to describe the evolution of fire by solving a large eddy simulation form of the Navier-Stokes equations $[9,10]$. The FDS is often combined with a specific software to create the input geometry such as PyroSim, and to read the FDS output files and produce animations such as Smokeview [6, 11, 12]. As Enright et al. [6] point out, although FDS is not specifically "validated" for jet vent air flows, CFD models in general are better predictors than empirical models.

The aim of this study was to design and evaluate a fire ventilation system with jet fans in an underground car park. The main task of the ventilation system was to remove burning polyurethane which generated high heat release and toxic fumes. Two alternative designs were tested, differing in the location of the jet fans and exhaust 
shafts, and in the air exchange rate. The FDS and associate computer programs were used to account for the complex geometry of the car park including walls, columns, beams, cars, and the jet fans.

\section{Combustion products originating from fire}

The combustion products originating from fire belong to the most serious pollutants that can occur in underground car parks. The knowledge obtained by studying the consequences of fire on human beings implies that combustion products can be even more dangerous to human health than the other fire related phenomena. The combustion products originating from fire diminish the oxygen content in the air, supress the ability of humans to think clearly, diminish visibility and orientation ability of evacuated people, and create preconditions for panic [13]. Besides, they directly affect human health in two different ways - as smoke and as toxic gasses. As the most dangerous combustion product is considered carbon monoxide, whose lower threshold for poisoning is the concentration of only 0.01 to $0.02 \%$ vol. At the concentration above $1 \%$ vol. humans lose consciousness and death occurs within three minutes. Poisoning by carbon monoxide presents a frequent cause of death in fires.

\section{Design and simulation models of the fire ventilation system}

Fire ventilation is not intended to provide fresh air in the car park, but it limits the smoke density and air temperature during a specified time interval to allow evacuation of people from the car park to a safe place. It is technically possible to combine fire, day to day and emergency ventilation into one system, keeping in mind that such a system has to fulfil the requirements imposed on all the individual ventilation types [14]. This is possible to accomplish with a jet fan ventilation system, which can be designed and operated as unidirectional or reversible. In case of fire, the ventilation system is switched up to a higher level. All fans used to exhaust hot gasses in a car park have to be tested and certified as defined in EN 12101-3 [15]. However, no standard to design fire safety systems that involve jet fans currently exists in Slovakia, and the design process usually follows the British Standard BS 7346-7:2013 [16].

\subsection{Design of the ventilation system}

The potential heat and combustion products generated in the underground car park of a commercial building were exhausted by an underpressure ventilation system with jet fans. The pressure difference between the exhaust and the supply was $20 \%$. The fresh ventilation air was supplied through an access ramp and five grilles. Two alternative designs were proposed. In the first alternative (A1) the space of the car park was divided into two imaginary parts, and the exhaust shafts were located in both of them. The jet fans were directed to the corresponding shafts as shown in Fig. 1. The air change rate was 10-times per hour. In the second alternative (A2) the exhaust shafts were located on the side opposite to the main air supply (access ramp), as shown in Fig. 2. The air exchange rate was 15-times per hour. Escape routes for the evacuated people are indicated in Figs. 1 and 2 by the red arrows.

\subsection{Simulation model}

The simulation model was created in PyroSim FDS 6.4.0 software [17], which also includes the Fire Dynamics Simulator. The model represents a controlled fluid flow during fire emergency. The calculation is governed by Navier-Stokes equations suitable for heat induced flows with low velocity to exhaust smoke and heat from the site, using the Dynamic Smagorinsky model [18, 19]. Smokeview 6.3.6 software [20] was used to visualise the fluid flow during fire emergency. The mesh size was $x=0.5 \mathrm{~m}, \mathrm{y}=0.5 \mathrm{~m}$, and $\mathrm{z}=0.25 \mathrm{~m}$. Simplified models of beams, columns,

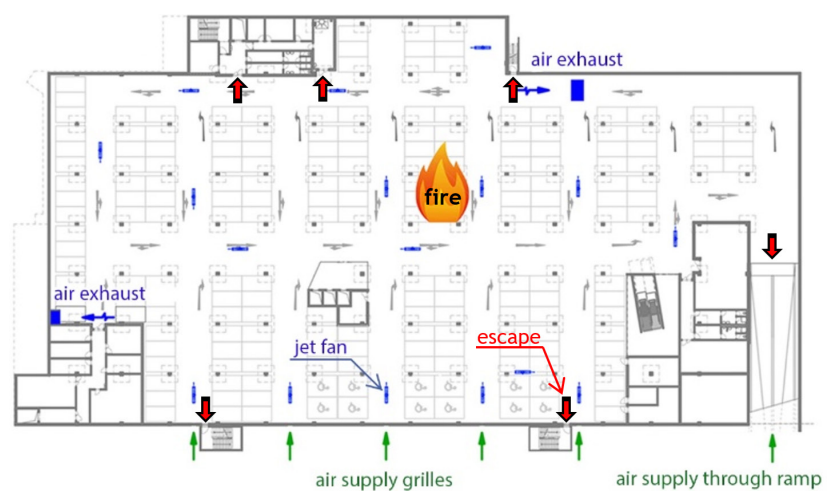

Fig. 1 Scheme of the fire ventilation system, alternative A1

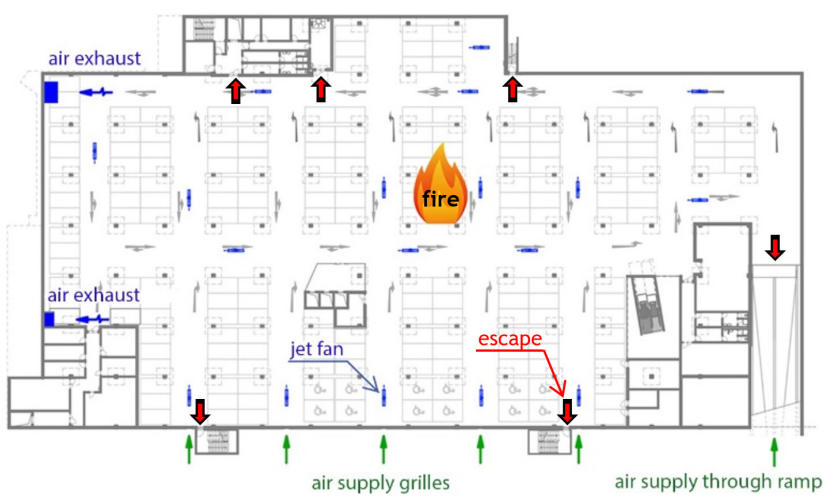

Fig. 2 Scheme of the fire ventilation system, alternative A2 
cars, and jet fans were included. The grid consisted of 393000 cells, and the simulation length was $1500 \mathrm{~s}$.

\subsection{Parameters of the fire}

The heat and pollution source was represented by burning polyurethane foam. Polyurethane is a material widely used in buildings, mainly as thermal insulation. It is flammable and on combustion it generates high heat release rates and toxic fumes containing a number of toxic products such as, e.g., carbon monoxide and hydrogen cyanide [21]. In our simulations a very sooty fire that represented burning of Polyurethane GM27 was used [22]. The soot yield was 0.1, which resulted in a large amount of smoke. The fire had a surface area of $9 \mathrm{~m}^{2}$, with a specific peak heat release rate of $500 \mathrm{~kW} \cdot \mathrm{m}^{-2}$ and an overall peak heat release rate of $4500 \mathrm{~kW}$. Details on the parameters of the fire are shown in Table 1. The fire developed from $0 \mathrm{~s}$ until $300 \mathrm{~s}$ according to the curve as shown in Fig. 3, and the mass flow rate of fuel was specified accordingly. The fire was then fully developed for $600 \mathrm{~s}$, after which it started to die away. At time $725 \mathrm{~s}$ the fire was put out and the fire emergency was terminated.

\section{Results and discussion}

In the first alternative (A1) the exhaust shafts were located in both parts of the car park and the jet fans were directed to the corresponding shafts. The air exchange rate was 10 -times per hour. During the fire, the combustion products spread throughout the whole car park. After $300 \mathrm{~s}$ the car park was completely polluted by the combustion products (Fig. 4a), and the visibility in escape routes was about 10 to $15 \mathrm{~m}$ (Fig. 4b). Despite the car park being ventilated after the fire had been put out, at time 1300 s, i.e. $575 \mathrm{~s}$ after the fire had been put out, it was still full of smoke (Fig. 5a). The average

\begin{tabular}{|c|c|}
\hline \multicolumn{2}{|c|}{ Polyurethane GM 27} \\
\hline Heat release rate & $500 \mathrm{~kW} \cdot \mathrm{m}^{-2}$ \\
\hline Dimensions of fire & $3 \times 3 \mathrm{~m}$ \\
\hline Location & $0.5 \mathrm{~m}$ \\
\hline \multicolumn{2}{|c|}{ Parameters of fire } \\
\hline Carbon atoms & 1 \\
\hline Hydrogen atoms & 0.17 \\
\hline Oxygen atoms & 0.3 \\
\hline Nitrogen atoms & 0.08 \\
\hline $\mathrm{CO}$ yield & 0.042 \\
\hline Soot yield & 0.1 \\
\hline Fraction of hydrogen & 0.1 \\
\hline
\end{tabular}

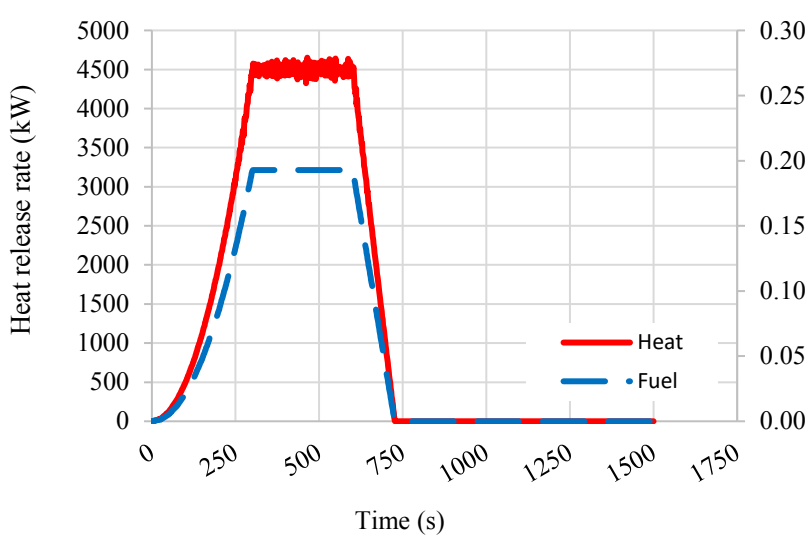

Fig. 3 Heat release rate of fire and mass loss rate of fuel specified in the simulations
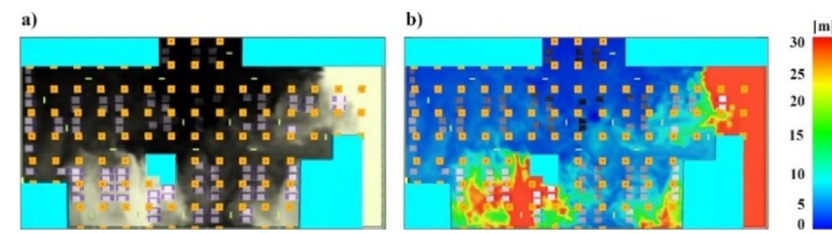

Fig. 4 Alternative A1 at time $300 \mathrm{~s}$ a) distribution of combustion products, b) visibility at $1.75 \mathrm{~m}$ above the floor level
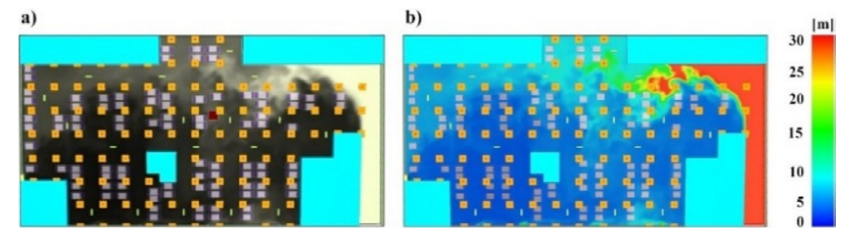

Fig. 5 Alternative A1 at time $1300 \mathrm{~s}$ a) distribution of combustion products, b) visibility at $1.75 \mathrm{~m}$ above the floor level

visibility was only $6 \mathrm{~m}$ at its maximum (Fig. $5 \mathrm{~b}$ ). The results for the alternative A1 reveal deficiencies in the design of the ventilation system. The low efficiency of fire ventilation is caused by inappropriate location of the exhaust shafts. Locating one of the shafts close to the access ramp caused that the ventilation air was not distributed properly throughout the car park, and a large part of the ventilation air was directly exhausted to the shaft.

In the second alternative (A2) both exhaust shafts were located on the side opposite to the main air supply (access ramp). Such location of exhaust shafts and air supply resulted in a massive fresh air intake, spreading through the whole car park. In this alternative the air exchange rate was 15 -times per hour. During the fire, the car park was flooded by combustion products (Fig. 6a), but the escape routes remained clear enough to allow safe evacuation of people. The visibility in the escape routes was about $25 \mathrm{~m}$ at time $300 \mathrm{~s}$ (Fig. 6b), and as the time passed it 

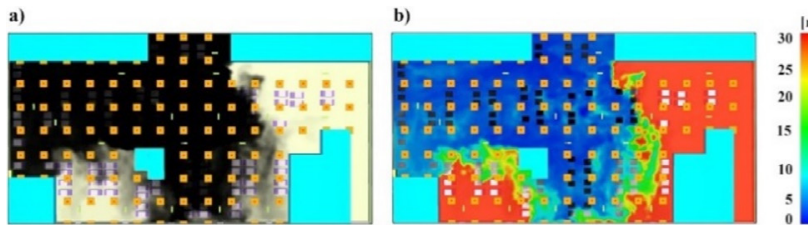

Fig. 6 Alternative A2 at time $300 \mathrm{~s}$ a) distribution of combustion products, b) visibility at $1.75 \mathrm{~m}$ above the floor level

diminished only to a small extent. After the fire had been put out, the space was massively ventilated and at time $1000 \mathrm{~s}$ the smoke pollution level was already very low. At time 1300 s, i.e. $575 \mathrm{~s}$ after the fire had been put out, the car park was ventilated completely (Fig. 7).

The CFD simulations indicate that the second alternative (A2) is preferable because, unlike the first alternative (A1), it is capable of ensuring safe evacuation of people from the car park. One of the parameters varied was the amount of fresh air intake. This parameter affected the speed of heat and smoke removal from the car park, but it had only minor effect on the efficiency of the ventilation system. Had the lower air exchange rate of 10-times per hour been used in the second alternative (A2), the efficiency of the fire ventilation system would still remain very high, only the time to ventilate the car park would have been slightly longer. On the other hand, had the higher air exchange rate of 15-times per hour been used in the first alternative (A1), the ventilation system would still not be able to sufficiently ventilate the car park. This means that location of the air supply and exhaust, and suitable positioning of the jet fans are crucial to attain high efficiency of fire ventilation systems with jet fans.

\section{Conclusion}

The results have shown that the fire ventilation system was not able to sufficiently ventilate the car park when the exhaust shafts were located in both parts of the car

\section{References}

[1] Kajtár, L., Kassai, M. "A new calculation procedure to analyse the energy consumption of air handling units", Periodica Polytechnica Mechanical Engineering, 54(1), pp. 21-26, 2010.

https://doi.org/10.3311/pp.me.2010-1.04

[2] Harmathi, N., Magyar, Z. "Influence of WWR, WG and Glazing Properties on the Annual Heating and Cooling Energy Demand in Buildings", Energy Procedia, 78, pp. 2458-2463, 2015.

https://doi.org/10.1016/j.egypro.2015.11.229

[3] Both, B., Szánthó, Z. "Experimental and Numerical Investigation of an Offset Jet Using Tangential Air Distribution System", Periodica Polytechnica Mechanical Engineering, 60(3), pp. 129-136, 2016. https://doi.org/10.3311/PPme.8017
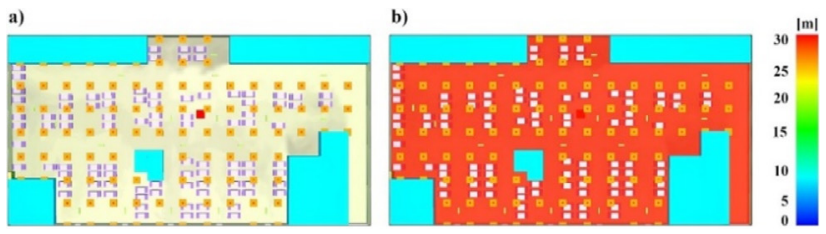

Fig. 7 Alternative A2 at time $1300 \mathrm{~s}$ a) distribution of combustion products, b) visibility at $1.75 \mathrm{~m}$ above the floor level

park and the jet fans were directed to the corresponding shafts (A1). Even $575 \mathrm{~s}$ after the fire had been put out the car park was still considerably polluted. Relocation of both exhaust shafts to the side opposite to the main air supply resulted in a massive amount of fresh air spreading through the whole car park (A2). Consequently, the car park was well ventilated, the escape routes were clear of smoke, and the pollution was exhausted in less than 600 seconds after the fire had been put out. The simulations have proven that proper location of the elements of the ventilation system is crucial to attain high efficiency of fire ventilation systems with jet fans. Although the air change rate is indeed an important parameter to consider, diminishing the ventilation intensity from 15 down to 10 air change rates per hour in this study would have only secondary effect on the efficiency of the fire ventilation system.

\section{Acknowledgement}

This work was supported by the Slovak Research and Development Agency under the Contract No. DS-20160030, by the Ministry of Education, Science, Research and Sport of the Slovak Republic under VEGA Grant 1/0807/17, and by the Competence Centre for SMART Technologies for Electronics and Informatics Systems and Services, ITMS 26240220072, funded by the Research \& Development Operational Programme from the ERDF. We support the research activities in Slovakia / The project is co-funded by the EU.

[4] Ahn, S.-J., Kwon, H.-M., Kim, G.-H., Yang, J.-H. "Study of Securing Required Ventilation Rates and Improving Mechanical Ventilation Systems for Underground Parking Lots", Journal of Asian Architecture and Building Engineering, 15(3), pp. 659-665, 2016. https://doi.org/10.3130/jaabe.15.659

[5] Deckers, X., Haga, S., Tilley, N., Merci, B. "Smoke control in case of fire in a large car park: CFD Simulations of Full-Scale Configurations", Fire Safety Journal, 57, pp. 22-34, 2013. https://doi.org/10.1016/j.firesaf.2012.02.005

[6] Enright, P. A. "Impact of jet fan ventilation systems on sprinkler activation", Case Studies in Fire Safety, 1, pp. 1-7, 2014. https://doi.org/10.1016/j.csfs.2013.11.002 
[7] Teixeira, J. C. F., Teixeira, S. F. C. F., Cunha, P., Silva, A. M. "Thermal Driven Dispersion of Smoke in a Parking Space", In: Proceedings of the ASME 2016 International Mechanical Engineering Congress and Exposition, Phoenix, Arizona, USA, V007T09A014, 2016.

https://doi.org/10.1115/IMECE2016-67498

[8] Viegas, J. C. "The use of impulse ventilation for smoke control in underground car parks", Tunnelling and Underground Space Technology, 25(1), pp. 42-53, 2010. https://doi.org/10.1016/j.tust.2009.08.003

[9] Lu, S., Wang, Y. H., Zhang, R. F., Zhang, H. P. "Numerical Study on Impulse Ventilation for Smoke Control in an Underground Car Park", Procedia Engineering, 11, pp. 369-378, 2011. https://doi.org/10.1016/j.proeng.2011.04.671

[10] Zhang, X. G., Guo, Y. C., Chan, C. K., Lin, W. Y. "Numerical simulations on fire spread and smoke movement in an underground car park", Building and Environment, 42(10), pp. 3466-3475, 2007. https://doi.org/10.1016/j.buildenv.2006.11.002

[11] Glasa, J., Valasek, L., Weisenpacher, P., Halada, L. "Use of PyroSim for Simulation of Cinema Fire" International Journal on Recent Trends in Engineering and Technology, 7(2), pp. 51-56, 2012.

https://doi.org/01.IJRTET.7.2.75

[12] Wadhwani, R., Sutherland, D., Ooi, A., Moinuddin, K., Thorpe, G. "Verification of a Lagrangian particle model for short-range firebrand transport", Fire Safety Journal, 91, pp. 776-783, 2017. https://doi.org/10.1016/j.firesaf.2017.03.019

[13] Oravec, M. "Manažérstvo priemyselných havárií", (Management of industrial accidents) ICV TU, Košice, Nová Lesná, Slovakia, 2011. (in Slovak)

[14] Úřad pro technickou normalizaci, metrologii a státní zkušebnictví "ČSN 736058 Jednotlivé, řadové a hromadné garáže" (Small, multi-storey and mass garages), ÚNMZ, Prague, Czech Republic, 2011. (in Czech)
[15] European Committee for Standardization "EN 12101-3 Smoke and heat control systems - Part 3: Specification for powered smoke and heat control ventilators (Fans), CEN, Brussels, European Union, 2015.

[16] BSI Group "BS 7346-7 Components for smoke and heat control systems. Code of practice on functional recommendations and calculation methods for smoke and heat control systems for covered car parks, BSI Group, London, United Kingdom, 2013.

[17] Thunderhead Engineering "Pyrosim - Fire Dynamics and Smoke Control", [online] Available at: www.thunderheadeng.com/pyrosim/ [Accessed: 13 May 2018]

[18] Smagorinsky, J. "General Circulation Experiments with the Primitive Equations: I. The Basic Experiment", Monthly Weather Review, 91(3), pp. 99-164, 1963.

https://doi.org/10.1175/1520-0493(1963)091<0099:GCEWT$\mathrm{P}>2.3 . \mathrm{CO} ; 2$

[19] Germano, M., Piomelli, U., Moin, P., Cabot, W. H. "A dynamic subgrid-scale eddy viscosity model", Physics of Fluids A: Fluid Dynamics, 3, pp. 1760-1765, 1991. https://doi.org/10.1063/1.857955

[20] McGrattan, K. B., McDermott, R. J., Weinschenk, C. G., Forney, G. P. "Fire Dynamics Simulator, Technical Reference Guide, Sixth Edition", Rep. Special Publication (NIST SP) - 1018, 2013.

[21] McKenna, S. T., Hull, T. R. "The fire toxicity of polyurethane foams", Fire Science Reviews, 5(3), pp. 1-27, 2016. https://doi.org/10.1186/s40038-016-0012-3

[22] Alarie, Y., Anderson, R. C. "Toxicologic classification of thermal decomposition products of synthetic and natural polymers", Toxicology and Applied Pharmacology, 57(2), pp. 181-188, 1981. https://doi.org/10.1016/0041-008X(81)90278-7 